\title{
Patterns in International Warfare, 1816-1965
}

\author{
By Melvin Small and J. David Singer
}

\begin{abstract}
Patterns in international violence are discovered through the quantitative analysis of international wars which resulted in more than 1,000 battle-connected deaths. Between 1816 and 1965, members of the state system participated in 50 such interstate wars and 43 such colonial and imperial conflicts. Although no secular trends are evident in terms of the frequency, magnitude, severity, and intensity of these wars, the data suggest a twenty-year cycle in the magnitude of systemic war. Over two thirds of all of the wars began in either the spring or the autumn. Major powers have engaged in a disproportionate number of wars and have suffered the most battle-connected deaths. These same powers, however, have won most of their wars. Those on the victorious side have often been the initiators of military hostilities. Enduring military friendships and enmities have been uncommon over the 150year period. Further use of these basic war data should be helpful in the assault upon the centuries-old problem of the causes of war.
\end{abstract}

Melvin Small, Ph.D., is an associate professor in the History Department of Wayne State University. A specialist in American diplomatic history, he is editor of Public Opinion and Historians (1970) and co-author of The Wages of War 1816-1965: A Statistical Handbook (1970). This past year, Professor Small was a recipient of an American Council of Learned Societies Study Fellowship and was a Fellow at the Center for Advanced Study in the Behavioral Sciences at Stanford, California.

J. David Singer, Ph.D., is professor of Political Science at the University of Michigan and is also a research political scientist at the university's Mental Health Research Institute. Professor Singer is author of Financing International Organization (1961), Deterrence, Arms Control and Disarmament (1962), and co-author of The Wages of War (1970), and editor of Human Behavior and International Politics (1965) and Quantitative International Politics (1968). He was a Fulbright Fellow in Oslo in 19631964 and a visiting scholar at the Carnegie Endowerment for International Peace in Geneva in $1967-1968$. 
GINCE Thucydides, scholars and statesmen have speculated about the causes and consequences of conflict between nation states. Despite the earnest efforts of countless generations of investigators, it is only within the past several decades that any promising attack on the problem of the causes of war has been mounted. In our judgment, the important turning point in man's long quest to understand this recurrent phenomenon occurred in the 1930's, when Quincy Wright and Lewis Richardson began to employ operational, quantitative techniques in the description and analysis of the most pernicious product of international relations. ${ }^{1}$

Inspired by the work of these pioneers, and borrowing many of their methodological and theoretical innovations, we have initiated a project whose major objective is to identify the variables that are most frequently associated with the onset of war, from the Congress of Vienna to $1965 .{ }^{2}$ Our first requirement was to describe and measure the dependent variable, and ascertain the trends and fluctuations in the frequency, magnitude, severity, and intensity of war during that period. This task has now been completed and the data base we have developed allows us to generalize with some degree of confidence about patterns in international violence over the last century and a half. ${ }^{3}$ Before we

1. Quincy Wright, A Study of War, 2 vols. (Chicago: University of Chicago Press, 1942); Lewis F. Richardson, Statistics of Deadly Quarrels (Chicago: Quadrangle, 1960). In the third volume of his Social and Cultural Dynamics (New York: American Book, 1937), Pitirim A. Sorokin also applied empirical techniques to a longitudinal study of warfare.

2. For a complete description of the project, see J. David Singer, "Modern International War: From Conjecture to Causality," in Albert Lepawsky ct al., Essays in Honor of Quincy Wright (in press).

3. Most of the material in this article is reported in other forms in J. David Singer and Melvin Small, The Wages of War, 1816-1965: A Statistical Handbook (New York: John Wiley, 1970). turn to such generalizations, however, we should explain briefly the data acquisition and coding procedures employed in our study,

\section{IDENTIFYING THE WARS}

Most major studies of war suffered from an absence of methodological precision and an invisibility of coding rules. ${ }^{4}$ These practices often resulted in the impressionistic analysis by anecdote of a few famous and large wars by political theorists, or the hyper-empirical analysis of every conceivable sort of violence by scholars with a mathematical orientation. Aware of the pitfalls inherent in both approaches, we have adopted criteria and rules which we feel allow maximum practicality and efficiency but which do not violate intellectual standards of reliability and validity.

Thus, we began by delimiting the system in which we were interested. Although it would be useful to know something about violence in all polities for all recorded time periods, such an approach would find us laboring far into the foreseeable future in the often barren vineyards of historiography. The period since 1815 , which is manageable in terms of the availability of historical sources, satisfies our need both for systemic continuity and for a time span long enough to allow for any permutations in the level of violence to evidence themselves. Within these temporal bounds, we were concerned with wars fought by members of the international system against fellow members (interstate wars) and against independent or

4. Even Wright and Richardson's pathbreaking works suffer from these shortcomings to some degree. Except for the most recent period, Wright did not order his study of wars in terms of magnitude or severity, nor did he present operational criteria for defining his universe. For his part, Richardson did not distinguish between the status of political entities engaged in conflict, nor was he interested in the casualties suffered by the separate participants in the wars he studied. 
colonial entities which did not qualify for membership in the system (extrasystemic wars). To qualify for membership in the international system, a state needed to have a population of at least 500,000 and diplomatic recognition from legitimizers within the international community. ${ }^{5}$ In the period after 1920 , membership in the League of Nations or the United Nations was used as an alternate criterion in some cases. The adoption of such a scheme results in a system with 23 members in 1816, 34 in 1870,61 in 1920 , and 124 in 1965.

As for the wars themselves, we gathered data on those conflicts in which the battle-connected deaths for all systemic combatants taken together surpassed 1,000. A slightly more complicated procedure was used to determine the inclusion or exclusion of some extra-systemic wars. ${ }^{6}$ (Civil wars, even those with foreign intervention, were not considered in this stage of the project.) AII the qualifying wars were codified in terms of severity (or battle deaths of system-member participants) and magnitude (or total number of nationmonths that system-member participants spent in combat). The 93 wars which met our criteria are listed in chronological order in Table 1, with the 50 interstate wars shown in italics. Alongside each war is its rank position in terms of battle deaths, nation months, and a simple intensity measure-number of battle deaths divided by number of nation months. ${ }^{7}$

5. A complete explanation of membership criteria is found in J. David Singer and Melvin Small, "The Composition and Status Ordering of the International System, 1815-1940," World Politics 18, no. 2 (January, 1966), 236282.

6. Because many nineteenth century imperial conflicts achieved a casualty level of 1,000 battle deaths only after five or ten years, we decided that such a conflict had to average 1,000 battle deaths a year for the system member in order to qualify for inclusion in our list.

7. Battle-death and nation-month scores for extra-systemic wars reflect only the war ex-

\section{TREnds AND Cycles}

After the basic data were reordered according to the amount of war begun, under way, and terminated each year, we were able to search for secular trends and periodicity over the past century and a half. Looking first at secular trends, contrary to what might have been expected, no trend, either upward or downward, is evident. That is, whether we concentrate upon frequencies, magnitudes, severities, or intensities, we do not find appreciably more or less war in any of the sub-epochs covered. Of course, there were more battle deaths in the twentieth century than in the nineteenth (thanks to the impact of the two World Wars and the Korean conflict), but when the figures are normalized for the number of nations in the system, this trend disappears. International war, therefore, appears to be neither waxing nor waning. It is true, however, that extra-systemic wars have been decreasing in frequency; but this is entirely a product of the liquidation of formal colonial empires and the expansion of the international system to include all independent entities.

While such findings might cheer those who intuitively feared that we have been experiencing an ever-increasing amount of war as we approach the apocalypse, they must be balanced with the more dismal finding that there appears to be a strong tendency toward periodicity in the system's war experiences. Although cycles are not apparent when we examine the amount of war beginning in each year or time period, a discernible periodicity emerges when we focus on measures of the amount of war under way. That is, discrete wars do not necessarily come and go with regularity but with some level of interstate violence almost

periences of system members. Many of these wars would have ranked considerably higher on all indices had we included non-member battle deaths and nation months. 
TABLE 1-BAsic Last OF International Wars, 1816-1965 $(\mathrm{N}=93)$

\begin{tabular}{|c|c|c|c|}
\hline \multirow[b]{2}{*}{ NAME OF WAK } & \multicolumn{3}{|c|}{ Rank Position } \\
\hline & BatTLE DEATHS & Nation MONTHS & $\begin{array}{l}\text { Battili: Digaths } \\
\text { PER } \\
\text { Nation MONTh }\end{array}$ \\
\hline British-Maharattan, 1817-1818 & 73.5 & 70 & 68.5 \\
\hline Greek Independence, 1821-1828 & 37.5 & 12 & 70 \\
\hline Franco-Spanish, 1823 & 89 & 52.5 & 90.5 \\
\hline First Anglo-Burmese, 1823-1826 & 37.5 & 29 & 52 \\
\hline Dutch-Javanese, $1825-1830$ & 37.5 & 17 & 70 \\
\hline Russo-Persian, 1826-1828 & 58 & 45 & 67 \\
\hline Navarino Bay, 1827 & 69 & 86.5 & 24.5 \\
\hline Russo-Turkish, 1828-1829 & 9 & 26.5 & 11 \\
\hline First Polish Insurrection, 1831 & 37.5 & 66 & 22 \\
\hline First Syrian, 1831-1832 & 46.5 & 52.5 & 46 \\
\hline Texan-Mexican, 1835-1836 & 89 & 70 & 83 \\
\hline First British-Afghan, 1838-1842 & 30 & 18 & 59 \\
\hline Second Syrian, 1839-1840 & 46.5 & 78.5 & 20 \\
\hline Peruvian-Bolivian, 1841 & 89 & 91 & 35 \\
\hline First British-Sikh, 1845-1846 & 78.5 & 83 & 54.5 \\
\hline Mexican-A merican, $1846-1848$ & 34 & 19 & 60.5 \\
\hline A ustro-Sardinian, 1848-1849 & 50.5 & 62.5 & 40 \\
\hline First Schleswig-Holstein, 1848-1849 & 55 & 47 & 62.5 \\
\hline Hungarian Revolution, 1848-1849 & 17.5 & 58 & 9 \\
\hline Second British-Sikh, 1848-1849 & 78.5 & 78.5 & 66 \\
\hline Roman Republic, 1849 & 73.5 & 70 & 68.5 \\
\hline La Plata, 1851-1852 & 82 & 56.5 & 85 \\
\hline First Turco-Montenegran, $1852-1853$ & 58 & 81 & 26.5 \\
\hline Crimean, $1853-1856$ & 6 & 6 & 17 \\
\hline Anglo-Persian, 1856-1857 & 73.5 & 65 & 72.5 \\
\hline Sepoy Mutiny, $1857-1859$ & 66 & 35.5 & 82 \\
\hline Second Turco-Montenegran, 1858-1859 & 69 & 56.5 & 71 \\
\hline Italian Unification, 1859 & 26 & 70 & 14 \\
\hline Spanish-Moroccan, $1859-1860$ & 46.5 & 62.5 & 35 \\
\hline Italo-Roman, 1860 & 89 & 91 & 35 \\
\hline Italo-Sicilian, 1860-1861 & 89 & 75 & 79.5 \\
\hline Franco-Mexican, 1862-1867 & 30 & 7 & 75.5 \\
\hline Second Polish Insurrection, $1863-1864$ & 58 & 50 & 64.5 \\
\hline Ecuadorian-Columbian, 1863 & 89 & 91 & 35 \\
\hline Second Schleswig-Holstein, 1864 & 61 & 59.5 & 62.5 \\
\hline La Plata, 1864-1870 & 11 & 5 & 41.5 \\
\hline Spanish-Chilean, 1865-1866 & 89 & 47 & 92.5 \\
\hline Seven Weeks, 1866 & 23 & 49 & 16 \\
\hline Ten Years, 1868-1878 & 12 & 8 & 41.5 \\
\hline Franco-Prussian, 1870-1871 & 7 & 30 & 8 \\
\hline Dutch-Achinese, $1873-1878$ & 55 & 16 & 87 \\
\hline Balkan, $1875-1877$ & 46.5 & 38 & 57 \\
\hline Russo-Turkish, 1877-1878 & 5 & 43 & 3 \\
\hline Bosnian Insurrection, 1878 & 66 & 83 & 31 \\
\hline Second British Afghan, 1878-1880 & 63.5 & 43 & 72.5 \\
\hline British-Zulu, 1879 & 66 & 75 & 50 \\
\hline Pacific, $1879-1883$ & 41 & 4 & 88.5 \\
\hline Franco-Indochinese, 1882-1884 & 61 & 31 & 75.5 \\
\hline Mahdist Insurrection, 1882-1885 & 30 & 21 & 54.5 \\
\hline Sino-French, 1884-1885 & 42 & 33 & 54.5 \\
\hline Central American, 1885 & 89 & 91 & 35 \\
\hline Serbo-Bulgarian, 1885 & 73.5 & 91 & 18 \\
\hline
\end{tabular}


TABIE $1 \cdots-($ Continued $)$

\begin{tabular}{|c|c|c|c|}
\hline \multirow[b]{2}{*}{ Name of War } & \multicolumn{3}{|c|}{ Rank Position } \\
\hline & Battle Deaths & Nation Months & $\begin{array}{l}\text { BaTtLE DEATHS } \\
\text { PER } \\
\text { NaTION MONTH }\end{array}$ \\
\hline Sino-Japanese, 1894-1895 & 37.5 & 47 & 38.5 \\
\hline Franco-Madagascan, 1894-1895 & 55 & 64 & 48 \\
\hline Cuban Revolution, 1895-1898 & 20 & 24.5 & 28 \\
\hline Italo-Ethiopian, 1895-1896 & 50.5 & 61 & 43 \\
\hline First Philippine Insurrection, $1896-1898$ & 73.5 & 35.5 & 88.5 \\
\hline Greco-Turkish, 1897 & 73.5 & 75 & 64.5 \\
\hline Spanish-American, 1898 & 46.5 & 67 & 30 \\
\hline Second Philippine Insurrection, 1899-1902 & 61 & 20 & 85 \\
\hline Boer, $1899-1902$ & 27 & 28 & 47 \\
\hline Russo-Japanese, 1904-1905 & 9 & 22.5 & 13 \\
\hline Central American, 1906 & 89 & 75 & 79.5 \\
\hline Central American, 1907 & 89 & 75 & 79.5 \\
\hline Spanish-Moroccan, 1909-1910 & 46.5 & 43 & 51 \\
\hline Italo-Turkish, 1911-1912 & 30 & 32 & 45 \\
\hline First Balkan, 1912-1913 & 15 & 39.5 & 10 \\
\hline Second Balkan, 1913 & 16 & 80 & 4 \\
\hline World War One, 1914-1918 & 2 & 2 & 5 \\
\hline Russian Nationalities, 1917-1921 & 20 & 22.5 & 29 \\
\hline Hungarian-Allies, 1919 & 43 & 55 & 44 \\
\hline Greco-Turkish, 1919-1922 & 20 & 13 & 49 \\
\hline Riffian Revolt, 1921-1926 & 25 & 15 & 60.5 \\
\hline Druze Rebellion, 1925-1926 & 63.5 & 35.5 & 75.5 \\
\hline Manchurian, 1931-19.33 & 17.5 & 26.5 & 20 \\
\hline Chaco, 1932-1935 & 9 & 14 & 20 \\
\hline Italo-Ethiopian, 1935-1936 & 30 & 52.5 & 26.5 \\
\hline Sino-Japanese, 1937-1941 & 4 & 9 & 7 \\
\hline Russo-Japanese, 1939 & 33 & 59.5 & 23 \\
\hline World War Two, 1939-1945 & 1 & 1 & 1 \\
\hline Russo-Finnish, 1939-1940 & 14 & 70 & 6 \\
\hline Indonesian Rebellion, 1945-1946 & 81 & 35.5 & 92.5 \\
\hline Indochinese Rebellion, 1945-1954 & 13 & 10 & 38.5 \\
\hline Madagascan Rebellion, 1947-1948 & 78.5 & 39.5 & 90.5 \\
\hline First Kashmir, 1947-1949 & 78.5 & 52.5 & 85 \\
\hline Palestine, 1948-1949 & 52 & 41 & 58 \\
\hline Korean, 1950-1953 & 3 & 3 & 12 \\
\hline Algerian Revolution, 1954-1962 & 37.5 & 11 & 79.5 \\
\hline Tibetan Revolt, 1956-1959 & 22 & 24.5 & 32 \\
\hline Russo-Hungarian, 1956 & 24 & 86.5 & 2 \\
\hline Sinai, 1956 & 69 & 86.5 & 24.5 \\
\hline Sino-Indian, 1962 & 89 & 86.5 & 54.5 \\
\hline Second Kashmir, 1965 & 53 & 83 & 15 \\
\hline
\end{tabular}

always present; there are distinct and periodic fluctuations in the amount of that violence. The twenty-year cycle in the amount of nation-months of war under way can be seen in the graph in Figure 1.

Others have discerned similar cycles which could be related, among other things, to the time needed for a genera- tion to "forget" the last bloody conflict. ${ }^{8}$ It must be remembered that such

8. See, for example, Frank H. Denton, "Some Regularities in International Conflict, 18201949," Background 9, no. 4 (February, 1966), 283-296; Frank H. Denton and Warren Phillips, "Some Patterns in the History of Violence," Journal of Conflict Resolution 12, no. 2 (June, 1968), 182-195; Edward R. Dewey, The 177 Year Cycle in War, 600 B.C.-A.D. 


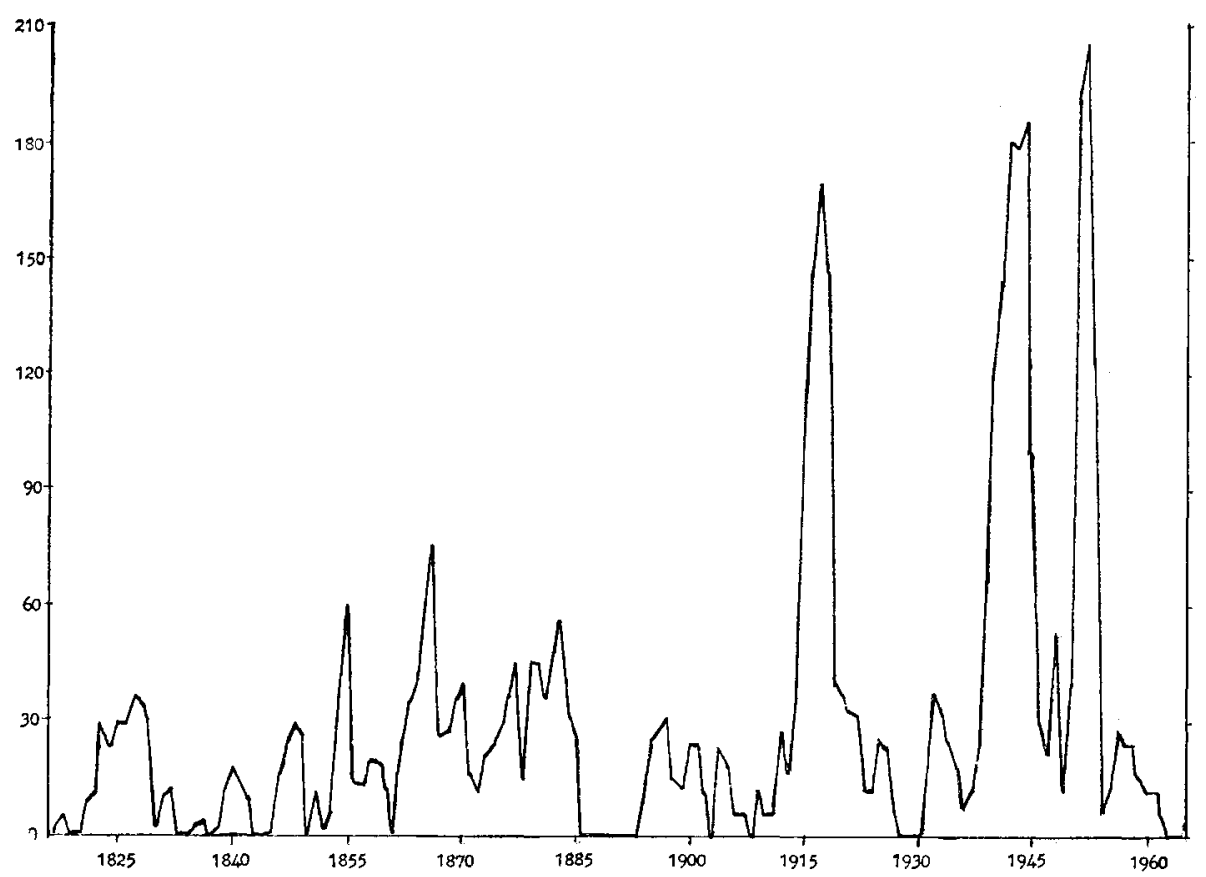

Figure 1. Annual Amount (in Nation Months) of International War Under Way $1816-1965$

analyses assume an interdependence between the martial activities of all system members, and that, for example, the incidence of war in the Balkans presumably affects the incidence of war on the Iberian Peninsula or even in Southeast Asia. Interestingly, no cyclical patterns are apparent when we examine the military experiences of the individual nations which participated in several wars. Thus, we must be rather tentative in affirming the existence of periodicity in the incidence of war, for our one strong pattern shows up only when we isolate one set of variables among many. Much more work needs to be done before we can accept completely the notion of a twenty-year cycle, although

1957 (Pittsburgh: Foundation for the Study of Cycles, 1964); J. S. Lee, "The Periodic Recurrence of Internecine Wars in China," The China Journal 14, no. 3 (March, 1931), 111-115, 159-162. these preliminary findings suggest the direction in which this work should go.

\section{SEASONS ANd Wars}

Another way to approach the temporal variable is to examine the relationship between season and month and the incidence of war. According to the folklore, the onset and termination of war should be determined, in part, by climatological conditions which might affect military mobility and efficiency, and the growing and harvesting seasons which might, in turn, affect provisioning and recruiting an army. Some contemporary analysts would expect most wars to begin between March 22 and April 20 under the sign of bellicose Aries, and the fewest to begin between September 24 and October 23 when the gentle Libra is dominant.

To some degree, our data support the common folklore although the verdict is mixed for the astrologists. Of the 93 
wars, 64 began in either spring or autumn and only 29 in summer and winter. Moreover, this pattern does not change much over time; for example, 11 of the 21 wars fought since 1920 began in autumn. As for specific months, April and October saw the initiation of 28 of the 93 conflicts, while long and bloody wars tended to begin in July and September. No one season or month stands out when it comes to the termination of war. This latter finding, when compared to the onset patterns, lends credence to the thesis that policy makers are influenced by the season when they consider a war/no-war decision, but that once the war is under way, more nonrational factors militate against weather or supplies playing such a crucial role. Of course, much of this is conjecture. Before we can attest with certainty to the proposition that weather and climate weigh heavily with the decision-maker, we must compare similar sets of crises, which did and did not terminate in war, with specific seasonal variables.

\section{The War Proneness of Nations}

Whereas systemic patterns of international violence are most interesting to the political theorist, the record of individual nations' martial activities has long fascinated historians. Many have argued that some nations (perhaps during certain periods) are more aggressive than others, or that some ethnic groups are naturally warlike whereas others are naturally pacific. At the same time, repeated involvement in war may not necessarily relate to any innate characteristic but merely to the misfortune of being geographically proximate to predatory powers. By computing the number and severity of wars experienced by each nation during its tenure in the system, we can obtain a more accurate indication of the distribution of wars among the nations, and whether, indeed, certain nations, or certain classes thereof, are more prone to war involvement than others.

In terms of the sheer number of international wars, France and England lead the field with 19 each, Turkey participated in 17, Russia 15, and Italy (including its predecessor, Sardinia) 11. All of these nations were members of the system for the full 150 years. Spain, which fought in 9 wars, and the United States, which fought in 6 , are two other charter members of the system with significant war experience. Those with a shorter tenure are led by Austria-Hungary with participation in 8 wars, Greece and Japan with 7, and Germany (includirig its predecessor, Prussia) with 6 . As might be expected, many of these nations also sustained the most battle deaths, with Russia, Germany, China, France, Japan, England, Austria-Hungary, Italy, and Turkey, in that order, all suffering 750,000 or more. Moreover, 39 percent of all the system's nation months of war were accounted for by 5 nations-France, England, Turkey, Spain, and Russia-whereas 39 of the 43 extra-systemic wars were fought by 7 states-England 12, France 7, Turkey 6, Russia 5, Spain 4, Holland 3, and Austria-Hungary 2.

Obviously, major powers were the most war-prone, with Turkey, Spain, and Greece the only non-majors to appear in this firmament. ${ }^{9}$ No major powers were able to escape this scourge, which may, in fact, turn out to be a prerequisite for achievement of that exalted status. On the other hand, most of the smaller states, and especially

9. Our major powers (reflecting the historians' consensus) were England 1815-1965, France 1815-1940, 1945-1965, Germany 18151918, 1925-1945, Russia 1815-1917, 1921-1965, Austria-Hungary, 1815-1918, Italy 1860-1943, United States 1899-1965, Japan 1895-1945, and China 1950-1965. 
TABLE 2-National Performances in Internationat. War, 1816-1965

\begin{tabular}{|c|c|c|c|c|c|}
\hline Nation Name & ALL WARS & $\begin{array}{l}\text { INTERSTATE } \\
\text { WARS }\end{array}$ & Nation Name & ALL WARS & $\begin{array}{c}\text { INTERSTATE } \\
\text { WARS }\end{array}$ \\
\hline England & $16-2$ & $6-0$ & China & $3-4$ & $2-4$ \\
\hline Russia & $13-2$ & $8-2$ & Bulgaria & $1-3$ & $1-3$ \\
\hline France & $14-4$ & $9-2$ & India & $1-2$ & $0-2$ \\
\hline Italy (Sardinia) & $8-3$ & $8-2$ & Mexico & $1-2$ & $1-1$ \\
\hline United States & $5-0$ & $4-0$ & Peru & $1-2$ & $1-1$ \\
\hline Brazil & $3-0$ & $2-0$ & Salvador & $1-2$ & $1-2$ \\
\hline Japan & $5-2$ & $5-2$ & Ecuador & $0-1$ & $0-1$ \\
\hline Yugoslavia (Serbia) & $4-1$ & $4-0$ & Hanover & $0-1$ & $0-1$ \\
\hline Rumania & $4-1$ & $4-1$ & Hesse Electoral & $0-1$ & $0-1$ \\
\hline Austria-Hungary & $5-3$ & $3-3$ & Hesse Grand Ducal & $0-1$ & $0-1$ \\
\hline Belgium & $2-0$ & $2-0$ & Iraq & $0-1$ & $0-1$ \\
\hline Chile & $2-0$ & $2-0$ & Jordan & $0-1$ & $0-1$ \\
\hline Germany (Prussia) & $4-2$ & $4-2$ & Lebanon & $0-1$ & $0-1$ \\
\hline Greece & $4-2$ & $4-2$ & Mecklenburg-Schwerin & $0-1$ & $0-1$ \\
\hline Holland & $3-1$ & $1-0$ & Persia & $0-1$ & $0-1$ \\
\hline Israel & $2-0$ & $2-0$ & Saxony & $0-1$ & $0-1$ \\
\hline Mongolia & $2-0$ & $2-0$ & Syria & $0-1$ & $0-1$ \\
\hline Spain & $5-4$ & $2-3$ & Bolivia & $0-2$ & $0-2$ \\
\hline Australia & $1-0$ & $1-0$ & Denmark & $0-2$ & $0-2$ \\
\hline Canada & $1-0$ & $1-0$ & Finland & $0-2$ & $0-2$ \\
\hline Colombia & $1-0$ & $1-0$ & Honduras & $0-2$ & $0-2$ \\
\hline Czechoslovakia & $1-0$ & $1-0$ & Morocco & $0-2$ & $0-2$ \\
\hline New Zealand & $1-0$ & $1-0$ & Papal States & $0-2$ & $0-2$ \\
\hline Nicaragua & $1-0$ & $1-0$ & U.A.R. (Egypt) & $0-2$ & $0-2$ \\
\hline Norway & $1-0$ & $1-0$ & Hungary & $0-3$ & $0-3$ \\
\hline Pakistan & $1-0$ & $1-0$ & Turkey & $5-11$ & 46 \\
\hline Paraguay & $1-0$ & $1-0$ & & & \\
\hline Portugal & $1-0$ & $1-0$ & & & \\
\hline Poland & $1-0$ & $1-0$ & & & \\
\hline South Africa & $1-0$ & $1-0$ & & & \\
\hline Baden & $1-1$ & $1-1$ & & & \\
\hline Bavaria & $1-1$ & $1-1$ & & & \\
\hline Ethiopia & $1-1$ & $1-1$ & & & \\
\hline Guatemala & $1-1$ & 1-1 & & & \\
\hline Two Sicilies & $1-1$ & $1-1$ & & & \\
\hline Württemberg & $1-1$ & $1-1$ & & & \\
\hline Argentina & $1-1$ & $0-1$ & & & \\
\hline
\end{tabular}

those in extra-European regions, enjoyed a fairly pacific record in terms of international war. Many of these, of course, experienced long and bloody civil conflicts. Still, the fact that more than half the nations ( 77 out of 144) which were at one time or another members of the system were able to escape international war entirely, suggests that military conflict between nations is not so common a systemic activity as some have posited.

\section{National Military Achievement}

Although some nations have fought in more wars than others, they have done so with varying degrees of success. Indeed, success in warfare might predict to frequency of involvement. A nation which loses several wars might behave with great circumspection in order to avoid the necessity of having to go to war again. Alternately, a military loss might foster a revanchist spirit, 
or worse yet, it could tempt a third power which felt it could easily defeat the nation whose military record was less than impressive. The data upon which one might base such generalizations are offered in Table 2, which shows each nation's record of victories and defeats in all international wars, followed by its record for interstate wars only. ${ }^{10}$ Experiences in the one stalemate (the Korean war) have been excluded from this tabulation.

Thanks to their choice of enemies and allies, as well as their military capabilities and skills, most of the major powers have done rather well. The nine nations which were at one time or another major powers hold six of the first seven positions and eight of the first thirteen in terms of won-lost records. The one major power absent from this galaxy, China, achieved its poor record while it was a minor power-since 1950 China has won two wars and tied in another. Turkey, as was expected, has a dismal history in this realm, but the Italians, often maligned for their legendary military ineptitude, nevertheless emerged victorious in eight of their eleven engagements.

\section{The Initiation of Interstate WaR}

A history of involvement in international war is a necessary but not suffcient indication of a nation's bellicosity. The determination of the initiator of military conflict, however, may tell us a bit more about a nation's aggressive proclivities. When we speak of initiation here, we are merely identifying the

10. In some cases, the distinction between victor and vanquished was difficult to make, but in the end we "declared" a victor in all but one of the wars. For our purposes, nations like Poland and Belgium in World War II, while defeated in the initial stages of the war, were considered victors since they emerged at war's end on the side of the winning coalition. nation(s) which made the first attack on an opponents' armies or territories. Clearly, initiator and aggressor are not always identical, as a participant might provoke its adversary into military action by mobilization or other aggressive diplomatic or economic actions. But the designation of the initiator of military aggression should nevertheless provide some tentative clues as to the relative belligerency of system members.

In examining the 49 interstate wars in which we were able to make this designation, we find that Italy was the actual initiator (or on the side of the initiator) on 8 occasions, France played that role on 6 occasions, Germany and Japan on 5, and Austria-Hungary, Russia, and Bulgaria on $4 .^{11}$ But when we turn from sheer number of initiations to the frequency of initiation compared to the total number of war experiences, some of the nations on this infamous list look a little less bellicose. Whereas Italy initiated or fought on the side of the initiator in 8 of her 10 interstate wars, Germany in 5 of her 6, Japan in 5 of her 7, Austria-Hungary in 4 of her 6, and Bulgaria in all of her 4, France initiated only 6 of her 12 interstate wars and Russia only 4 of her 10 . Among those nations with significant war experience which are absent from this list and therefore, perhaps, more pacific, are: the two "sick men" of Asia, Turkey and China; three Balkan states, Greece, Rumania, and Yugoslavia; and the two Anglo-Saxon major powers, England and the United States.

The decision to initiate hostilities is related, in part, to the expectation of victory. Few governments would move first militarily unless they expected that

11. The one case which we did not include in this analysis was the Navarino Bay incident of 1827 . In several other wars, the labeling of one side as initiator came only after long and troubled consideration. 
such preëmption had a high probability of victory or, at least, of national survival. Not surprisingly, then, we find that initiators emerged victorious in 34 of the 49 interstate wars although they lost 14 times and experienced one stalemate. As for battle fatalities, in 36 of those 49 , the initiators lost fewer men than their opponents, and they were victorious in 6 of those 13 wars in which their losses were greater than their opponents'. This is an impressive record when one considers that an attacking force is generally assumed to lose more men than a defending force in a given engagement.

Of course, in almost 40 percent of the cases, the initiator turned out to be a major power attacking a minor power. Of the 19 wars which saw such a onesided confrontation, the major power initiated hostilities on 18 occasions and won 17 of those 18 contests. ${ }^{12}$ When minors fought minors, the initiator won 14 times and lost 7, but when majors fought majors, the initiators won 3 times and lost 5. Thus, initiation of hostilities appears to have been a major advantage to the combatants, but an advantage which decreased in importance when the two sides were more nearly equal in power.

\section{Traditional Enmities and FRIENDSHIPS}

A nation's record of participation, as well as of success and of failure, in war has something to do with its historic long-term relationship to other nations. Historians and political scientists have written about the importance of traditional enmities and friendships between nations, and speculated as to whether similar governments, religions, ethnicity, or stages of economic development affect the propensity of nations to war against,

12. In 17 of these wars, the major power shared a border with the minor power. or ally with, one another. Moreover, the experience of conflict against or alliance with a state in one war should affect future relations with that state in other wars and crises. In the Statistics of Deadly Quarrels, Richardson reported that 48 percent of the pairs who fought on opposite sides in all wars from 1820 to 1949 , fought against each other on more than one occasion. But he also found that 29 percent of those pairs who had been allies in one war had already fought against each other in an earlier experience. $^{13}$ Looking at our more restricted set of wars, we find somewhat less evidence for the prevalence of historical enmities and alliances.

Of the 209 pairs who fought opposite each other in our 50 interstate wars, only 19 percent had fought against each other before, while 21 percent had been allies in an earlier war. As for those pairs with more than one experience in war (136), of the 95 pairs with some experience as opponents, 77 of them also fought at least once on the same side.

Thus, in terms of war experience, few friendships or enmities have held up throughout our 150-year period. When we look only at those nations with 3 or more experiences as allies and none as opponents in that period, we find that France and England have been partners on 6 occasions, Greece and Yugoslavia on 4, and Belgium, England and France, Greece and England, Holland and England, and the United States, England, and France on 3. As for historical enmities, those with 3 or more experiences as opponents and none as allies are Russia and Turkey with 5 conflicts, AustriaHungary and Italy, and China and Japan with 4, and Germany and France with 3. While these listings conform to the historians' generalizations, the large number of possible dyadic relationships requires us to conclude that the notion

13. Richardson, op. cit., 196-199. 
of enduring and traditional relationships in war applies only to a limited number of famous pairs.

\section{Conclusion}

The above figures provide a brief, and necessarily superficial, overview of the incidence of war in the modern international system. While they are of some intrinsic interest, their major value is more instrumental in nature. That is, with such data as summarized here (and reported more fully in our Wages of War) an accelerated assault on the problem of the causes of war becomes feasible. A variety of researchers, reflecting diverse disciplines and numerous theoretical orientations, can now undertake a systematic search for the factors which account for this organized tribal slaughter. Whether the focus be on economic or strategic, psychological or technological phenomena, the dependent variable data are now at hand. Our major purpose was to make such research possible, and as we explore the problem from our particular point of view, we hope others will do likewise. Although the odds do not seem particularly favorable, we might just unravel the mystery of war's regularity before we stumble into its final occurrence. 